\title{
What Firms Make vs. What They Know: How Firms' Production and Knowledge Boundaries Affect Competitive Advantage in the Face of Technological Change
}

\author{
Rahul Kapoor \\ INSEAD \\ Boulevard de Constance \\ 77305 Fontainebleau Cedex, France \\ Tel: +33160712576 \\ Email: rahul.kapoor@insead.edu \\ Ron Adner \\ INSEAD \\ Boulevard de Constance \\ 77305 Fontainebleau Cedex, France \\ Tel: +33160724470 \\ Email: ron.adner@insead.edu
}

\section{December 2007}

\begin{abstract}
Product innovations are often enabled by changes in components. We examine how firms' ability to manage such changes depends on their governance strategies, their knowledge of components, and the nature of technological change. Using data on all firms in the DRAM industry across 12 technology transitions from 1974 to 2005, we find that vertically integrating into component production improves firms' ability to manage technology transitions. Although non-integrated firms have lower performance, this effect is muted by the firms' component knowledge. Moreover, the relative advantage of extending production vs. knowledge boundaries is determined by two factors. The first is the nature of technological change - integrated firms have a greater advantage over non-integrated firms when innovation is architectural than when it is incremental. The second is the degree of integration - non-integrated firms derive greater benefit from their knowledge of external components than do integrated firms. Our results clarify the conditions under which extending knowledge boundaries can be a substitute for extending production boundaries in managing technological change.
\end{abstract}

We thank Phil Anderson, Matthew Bidwell, Javier Gimeno, Connie Helfat and Peter Zemsky for useful comments. We would like to especially thank VLSI Research, Brian Grenon, Jim Reynolds, Jeff Macher and Michael Leiblein for their generosity in sharing their data with us. Finally, our thanks to many industry professionals with whom we have had the pleasure to discuss their experiences. All errors remain our own. 


\section{INTRODUCTION}

New product innovations are often enabled by changes in components within existing and new architectures (Rosenberg, 1976; Hughes, 1983; Henderson and Clark, 1990; Christensen, 1992, Henderson, 1995). Scholars have uncovered important mechanisms by which new innovations affect the performance advantage of firms. The examinations include the roles of firms' existing competencies (Tushman and Anderson, 1986), cognitive frames and routines (Henderson and Clark, 1990), complementary assets (Tripsas, 1997) and resource allocation processes (Christensen, 1997). While multifaceted, these studies have tended to concentrate on how the characteristics of an innovation interact with firms' internal resources and product development routines to affect performance. In so doing, they have tended to overlook the interaction with firms' external dependencies.

Specifically, the innovation literature has often assumed that all components are produced and integrated by the focal firm (e.g., Henderson and Clark, 1990: 10). Firms, however, often rely on external suppliers for their components. Indeed, as numerous studies have highlighted (e.g., Monteverde and Teece, 1982; Walker and Weber, 1984; Argyres, 1996; Leiblein and Miller, 2003), whether firms produce components internally or source them externally is a choice that depends on firms' capabilities, economies of scale and scope, and the transaction costs associated with the development of components. In this paper, we examine how firms' performance in the face of technological change depends not only on the characteristics of the innovation, but also on the extent of their involvement in both the production as well as the knowledge of key components.

Transaction cost economics (TCE) has been a key theoretical lens used by scholars to evaluate how firms manage coordination problems in the vertical chain. According to TCE, the 
choice of vertical integration is based on the characteristics of transactions between two contracting parties (Williamson, 1985). In the context of innovation, such transactions may occur during the development and integration of components into the final product. Scholars in innovation have suggested an important link between firms' governance mode and their ability to manage new innovations (Teece, 1996; Chesbrough and Teece, 2002; Afuah, 2001). The uncertainty coupled with transaction specific investments that accompany an innovation creates contracting problems and hence, makes governance critical to the success of firms' innovation efforts.

While the dominant focus of firm boundary choice has been on the make-or-buy decision, recent evidence suggests that firm's vertical scope decision also encompasses choice with respect to integration of knowledge; i.e., instead of investing in production, firms may invest in knowledge of activities even if the activities are outsourced (Patel and Pavitt, 1997; Fine, 1998; Brusoni et al., 2001). This knowledge may help firms to better manage the coordination challenges in the vertical chain by selecting suitable suppliers and by improving the governance in the vertical chain through crafting of superior contracts and more effective monitoring mechanisms (e.g., Mowery, 1983; Mayer and Salomon, 2006; Argyres and Mayer, 2007).

In this paper, we consider settings in which innovation efforts are characterized by high transaction costs such that firms may improve their coordination of technological changes in components through vertical integration. We examine how firms' vertical scope, measured through both production and knowledge of key components, affect their effectiveness in managing the technological changes underlying their innovation efforts. We evaluate this effectiveness according to the speed with which firms' commercialize new technology generations. We consider how the decision to vertically integrate is determined not only by 
transaction costs but also by firms' capabilities and production economies. We argue that while vertically integrated firms are likely to gain advantage from extending their production boundaries to encompass component production, non-integrated firms will offset their disadvantage by investing in the knowledge of components i.e., by extending their knowledge boundaries. ${ }^{1}$ Finally, we predict that the disadvantage from non-integration will be influenced by the nature of technological change: non-integrated firms will be more disadvantaged when technological change is architectural than when it is incremental.

We test our predictions in the dynamic random access memory (DRAM) industry from 1974 to 2005 , a period during which the industry transitioned through 12 distinct technology generations that were critically enabled by changes in components. The 12 technology transitions can be clearly classified as either incremental or architectural (Henderson and Clark, 1990), such that the interactions between transition types and firm strategy are well characterized. Also, because DRAMs of a given technology generation are homogenous goods (Irwin and Klenow, 1994), comparisons between firms time to commercialization offer a particularly crisp measure of performance. Hence, the DRAM industry is an especially good context in which to test our arguments.

We find that vertically integrating into component production improves firms' ability to manage technology transitions. Although non-integrated firms have lower performance, this effect is muted by the firms' component knowledge. Moreover, the relative advantage of extending production vs. knowledge boundaries is determined by two factors. The first is the nature of technological change: integrated firms have a greater advantage over non-integrated firms when innovation is architectural than when it is incremental. The second is the choice of

\footnotetext{
${ }^{1}$ We note that firms' knowledge boundaries may be broader than what we have considered in this study. Our conceptualization is consistent with prior research that has examined firms' knowledge in the context of activities in the vertical chain (e.g., Fine, 1998; Brusoni et al., 2001; Takeishi, 2002).
} 
vertical integration: non-integrated firms derive greater benefit from their knowledge of external components than do integrated firms.

Prior research in innovation has emphasized internal challenges that firms face during periods of technological change (e.g., Tushman and Anderson, 1986; Henderson and Clark, 1990, Christensen, 1997). Firms, however, often depend on external suppliers for their innovation, and coordination of technological changes across different components may play no less a role in shaping firms' performance. Our examination of such coordination challenges across 12 different technology transitions sheds important light on how firms' production and knowledge strategies within its vertical chain affect their ability to commercialize new innovations. Our results also extend the emerging literature that integrates transaction cost economics with competence based perspectives (e.g., Leiblein and Miller, 2003; Jacobides and Hitt, 2005; Hoetker, 2005; Mayer and Salomon, 2006). We show that while knowledge of external activities may improve firms' governance capabilities, its effect may be muted for partially integrated firms that have a lower reliance on external suppliers. Finally, we contribute to the emerging literature of innovation ecosystems by explicitly recognizing that the success of firms' innovation efforts depends on other innovations in the firms' environments (e.g., Afuah and Bahram, 1995; Adner and Kapoor, 2006; Adner, 2006; Gawer and Henderson, 2007), and by showing how firm strategies interact with technological changes in the environment to influence performance outcomes.

\section{THEORY AND HYPOTHESES}

\section{Technological Change and Firm Performance}


Technological progress in an industry is characterized by long periods of incremental improvements punctuated by radical changes (Abernathy and Utterback, 1978; Sahal, 1981; Dosi, 1982; Tushman and Anderson, 1986). Radical changes occur when core technological concepts underlying a given product are transformed, and followed by emergence of a new dominant design (Abernathy and Utterback, 1978; Anderson and Tushman, 1990). Incremental changes are more subtle, such that core technological concepts are reinforced and progress takes place along continuous technological trajectories (Dosi, 1982). The theoretical discussions in the strategy and innovation literatures have provided a rich set of insights on how technological change affects firms. Empirical examinations, however, have focused on understanding the performance differences of incumbents vs. entrants by focusing on the internal challenges that firms face in creating new innovations (e.g., Tushman and Anderson, 1986; Henderson and Clark, 1990; Christensen, 1997). In this study, we complement the earlier literature by focusing on the more common form of competition in technology based industries - an incumbent vs. other incumbents during periods of incremental technological change (c.f., BusinessWeek, 2006), and we focus on the external challenges that firms face in coordinating technological changes in the vertical chain (Teece, 1996; Afuah, 2001).

\section{Firm's Vertical Scope and Management of Non-Radical Technological Change}

We conceptualize product as composed of components that are themselves arranged in an architecture, and then examine how a firm's production and knowledge boundaries with respect to key components affect its ability to make technological progress by introducing new innovations. In this discussion, we only consider technological changes in which core technical concepts are reinforced, not overturned. Hence, we constrain the type of innovations to either 
incremental or architectural (Henderson and Clark, 1990). Such innovations are enabled by technological changes in components along pre-existing trajectories (e.g., Henderson and Clark, 1990; Christensen, 1992; Henderson, 1995).

From the point of view of an innovating firm, managing technological changes in components requires close coordination between activities that underlie the development of components and their integration into the final product. This is especially true when such components advance at non-uniform rates (Rosenberg, 1976; Hughes, 1983) or have technological interdependencies that require experimentation and learning for their potential to be realized (Iansiti, 1998).

Transaction cost economics (TCE) has been a key theoretical lens used to explain how firms could manage coordination between upstream and downstream activities through a makeor-buy choice. TCE views the make-or-buy decision by the firm as a solution to minimizing transaction costs. Hence, the efficient form of organization for a particular transaction is deduced based on key properties of the transaction: asset specificity, uncertainty and frequency (Williamson, 1985). Of the different transaction characteristics, asset specificity has received the most attention in the empirical literature as it plays a central role in the transaction cost approach to vertical integration (Williamson, 1985, p. 56). Asset specificity refers "to the degree to which an asset can be redeployed to alternative uses and by alternative users without sacrifice of productive value". Williamson (1991, p. 281) has identified at least six different types of asset specificity: site specificity, physical asset specificity, human asset specificity, brand-name capital, dedicated assets and temporal specificity.

In the context of innovation, an iterative process of component development and integration may require extensive interactions between employees from the firm and the 
upstream component supplier resulting in high human asset specificity (e.g., Monteverde and Teece, 1982; Monteverde, 1995). In addition, such transactions are also typically characterized by high degree of temporal coordination between component and product development and hence, subject to temporal specificity (Wheelwright and Clark, 1992).

Vertical integration of key technological components characterized by high asset specificity would facilitate the commercialization of new innovation by mitigating contractual hazards associated with the asset specificity. Such hazards may result in poor product quality or delays in new product introductions where suppliers operating under different incentive conditions may behave opportunistically (Masten, 1996; Teece, 1996). Hence, we expect that firms' vertical integration of component characterized by high asset specificity would provide superior coordination of activities during the commercialization of the new innovation:

Hypothesis 1: Vertical integration of a component characterized by high asset specificity will improve a firm's performance in a new product technology.

Even if the likelihood of contractual hazards in the vertical chain may suggest internalizing the production, firms may not be able to do so. First, firms may not enjoy production economies and hence, have higher production costs than their suppliers (e.g., Walker and Weber, 1984). Second, firms may not have the capability associated with the development and production of key technological components (e.g., Argyres, 1996; Leiblein and Miller, 2003; Hoetker, 2005). Finally, the likelihood of technological obsolescence associate with components may also dissuade vertical integration (e.g., Balakrishnan and Wernerfelt, 1986). Such constraints to internalizing the production are especially relevant in industry contexts in which innovations are created through the combination of multiple component technologies advancing 
rapidly such as in the medical, transportation, telecommunications, electronics and information based industries.

While the strategic choice of firm's production boundaries is important, it is not the only dimension along which firm strategies for component technologies may be evaluated. For example, Patel and Pavitt (1997) provided comprehensive evidence that the production boundaries of the world's largest corporations are significantly narrower than their knowledge boundaries. They found that many firms develop competencies in a given technological field (as measured by patents) even through they do not actively participate in the relevant product market. Similar findings have been reported in the aerospace and the automotive industries i.e., firms invest in knowledge of components even if the components are fully sourced through the market (Fine, 1998; Brusoni et al., 2001; Takeishi, 2002; Ahmadjian and Lincoln, 2001).

Firm's investment in knowledge of components may facilitate the governance of activities in the vertical chain by reducing information asymmetry. More specifically, the knowledge is likely to influence governance through at least three different mechanisms. First, the knowledge may allow firms to select superior suppliers and avoid problems of low quality or longer development times. Second, the knowledge may also help firms to craft better ex ante contracts. Such contracts would clearly identify roles and responsibilities of the partners, detailed project milestones, monitoring mechanisms, contingency planning and knowledge sharing between parties. Finally, the knowledge may allow firms to monitor upstream activities more effectively by evaluating supplier investment and progress during development and identifying detailed specifications to asses the quality of the inputs. For example, Ahmadjian and Lincoln (2001) provide evidence of how Toyota's investment in knowledge of electronics improved its governance of activities with its key supplier, Denso: 
Some supporting evidence comes from our interviews with Toyota engineers who stated that the quality of Toyota's discussions with Denso about parts design and manufacturing had risen since Toyota's investment in electronics learning began. Before, they said, Toyota people sometimes asked silly or naive questions in procurement negotiations with Denso. Now that Toyota was acquiring a solid knowledge base in the technology, the communication between the companies has improved (pp. 689).

Hence, we expect that knowledge of component will facilitate firm's governance in the vertical chain and offset the negative impact of under-integration i.e., not internalizing the production of component with high transaction cost.

Hypothesis 2: In the absence of vertical integration, a firm's knowledge of the external component will improve its performance in a new product technology.

Innovation within a product architecture requires not only the integration of individual components but also the coordination of interactions between different components. While technological progress in components along pre-existing trajectories allow for new innovations, these innovations may vary in their extent of "changes" in interactions between components (e.g., Henderson and Clark, 1990; Christensen, 1992; Henderson, 1995). According to Henderson and Clark, "architectural innovation is often triggered by a change in a component perhaps size or some other subsidiary parameter of its design - that creates new interactions and new linkages with other components in the established product" (p. 12). Business and technology historians have provided numerous instances in which changes in a given component technology often creates "disturbances" which are eventually resolved through modifications in other parts of the architecture (Rosenberg, 1976 and 1982; Hughes, 1983). These modifications may be through changes in other components as well as through changes in the interactions between components. 
The architecture of a product may include components that are produced by the firm or its suppliers. Henderson and Clark (1990) only considered product innovations in which the components are designed, engineered, manufactured and integrated by a single firm (p. 10). Hence, their arguments with respect to coordination routines to commercialize new innovations were directed at units within an organization. However, these arguments may also be applied when components are produced by the firm's suppliers. Just as the interactions within a firm are characterized by communication channels, information filters and problem solving strategies, so too are the interactions between the firm and its suppliers (e.g., Dyer and Nobeoka, 2000; Takeishi, 2002) which may require greater adaptation during an architectural innovation. While Henderson and Clark (1990) provided convincing evidence from the semiconductor lithography alignment equipment industry that architectural innovation was a major reason for incumbent's failure during technology transitions, subsequent research in other contexts has provided mixed findings. For example, Christensen and Rosenbloom (1995) showed that in the disk drive industry, incumbents were successful in commercializing new architectural innovations as long as the innovation was developed and deployed within the same value network. However, as Chesbrough (2001) notes, incumbents in the semiconductor lithography alignment equipment industry were operating in the same value network and were still adversely affected by the architectural innovation.

We suggest that this inconsistency in findings can be resolved through closer examination of the interaction between firms' production boundaries and the nature of technological change. In the semiconductor lithography alignment equipment industry, three of the four architectural transitions changed the relationship between the lens and other components of the system (Henderson and Clark, 1990, p. 23). Incumbent firms who relied on external lens suppliers to 
commercialize the new innovation exited the industry when confronted with architectural innovations. ${ }^{2}$ However, the one firm that produced its own lens (Canon), despite facing significant challenges due to architectural innovation continued to be an important industry participant during and after the transition. Similarly, in the disk drive industry, the two technology innovations in which existing value networks were preserved and incumbents were able to successfully commercialize architectural innovations were the change from removable disk-pack drives to 14 inch Winchester drives and the transition from 3.5 inch to 2.5 inch drives. In both of these cases, vertically integrated incumbents such as IBM, Control Data, Toshiba, Hitachi and Fujitsu, which manufactured their own key components of magnetic disk and drive heads were successful (Christensen, 1993; Christensen and Rosenbloom, 1995; Christensen et al., 2002). Hence, it does seem that across both industry settings, firms that were vertically integrated in the production of key components performed better with architectural innovations. This observation is in line with Teece's (1996) proposition that integrated firms fare better in commercializing innovations that require "coordinated adjustment" throughout the technological architecture:

What is needed to successfully develop and commercialize systemic innovations are institutions with lowpowered incentives, where information can be freely shared without worry of expropriation, where entities can commit themselves and not be exploited by that commitment, and where disputes can be monitored and resolved in a timely way. This is precisely what multi-product integrated firms achieve. (p. 219)

The above discussion suggests that vertically integrated firms may be able to better coordinate technological changes in interactions that underlie an architectural innovation. This prediction is consistent with TCE. The changes in interactions between components during an architectural innovation are likely to increase the uncertainty associated with the coordination of

\footnotetext{
${ }^{2}$ An incumbent firm, GCA, acquired a lens maker, Tropel, in 1982 but continued to rely on an external supplier for most of its technical and commercial needs (Henderson, 1988: 227).
} 
various tasks. An increase in uncertainty coupled with greater asset specificity would exacerbate the transaction cost and hence, further increase the advantage of hierarchy over markets as a preferred organization mode to minimizing contractual hazards (Williamson, 1985). Hence, the negative effect of firm's under-integration will be greater for an architectural innovation than for an incremental innovation.

Hypothesis 3: In the absence of vertical integration, a firm will be more disadvantaged during an architectural change than during an incremental change.

\section{INNOVATION IN THE DRAM INDUSTRY}

The context for our study is the global dynamic random access memory (DRAM) industry. This industry is an ideal setting to test the hypotheses. Technological progress in the DRAM industry during the period of study has been enabled by changes in components along existing technological trajectories. This resulted in DRAM innovations being either incremental or architectural, providing us with a natural control to test our hypotheses. Throughout the industry's history, the key component technologies have been characterized by high asset specificity during commercialization of new innovations, such that the setting provides a valid test for TCE predictions. Finally, new DRAM innovations represent homogenous goods (Irwin and Klenow, 1994). Therefore, each firm introduces the new innovation with the same product characteristics. Hence, comparing differences in firm performance for a given product innovation is less likely to suffer from biases that certain product attributes may not be observable to the researcher.

\section{Data}


We used both primary and secondary data for this study. The primary data was collected through a series of interviews with industry experts over a period of 18 months. The secondary data was collected from semiconductor industry analysis firms, industry publications and US Patent and Trademark Office (USPTO). Table 1 provides the details of the sources of secondary data that we used in the study to carry out the quantitative analysis. Our sample includes every firm that ever sold a DRAM on the open market. ${ }^{3}$ We identified a total of 36 firms in the DRAM industry that competed in 12 distinct DRAM generations ranging from 4 Kilobit to 1 Gigabit memory density from 1974 to 2005 . In this study, we only consider the performance of incumbent firms (that is, we include firms as of their second generation of DRAM production) Note that incumbent firms have been the leading innovators in the industry, consistent with the presence of significant learning curve effects and the total absence of successful radical (Cooper and Schendel, 1976) and disruptive (Christensen, 1997) innovations.

(Insert Table 1 about here)

\section{Component Technologies and Technological Change in the DRAM Industry}

Since its emergence in the late 1960s, the DRAM industry has been viewed as a main engine of growth for the entire semiconductor value chain. Due to advances in computing applications, DRAM firms are faced with a continuous need to introduce new generations that increase the memory density of the DRAM chip. The memory density of the DRAM chip is defined based on the number of "bits" of binary data that the chip can store. For example, the 1 megabit (1M) DRAM chip can store $1 \times 10^{6}$ bits of data. Each bit on the chip is stored in a memory cell - a simple electric circuit of transistor and capacitor. The $1 \mathrm{M}$ generation was

\footnotetext{
${ }^{3}$ We do not have data on the small number of firms that produced DRAMs exclusively for their own in-house use.
} 
succeeded by the $4 \mathrm{M}$ generation, which increased memory density, and could store $4 \times 10^{6}$ bits of data on the chip. The increase in the density of the DRAM is achieved by increasing the number of cells in the chip. However, the increase in the number of cells per chip can only be economically viable if the size of the cell is reduced. This reduction is constrained by the design of the integrated circuits, the materials from which the chip is composed, and the process used to manufacture the circuits.

The core capabilities of the DRAM firms encompass product design, process technology and manufacturing engineering (Burgelman, 1994). The process technology and the manufacturing engineering groups can be considered as part of the DRAM firm's manufacturing capability. The successful commercialization of a new DRAM generation requires codevelopment of product design and process technology to achieve the required DRAM density. Once the new product is developed and commercialized, the focus moves to manufacturing engineering to scale up the process to achieve large volumes with high yields. Among the many processes required to manufacture a DRAM, the lithography process plays the most critical role in reducing the cell size and allowing for the introduction of new DRAM generations (Johnson and Mack, 1992; Okazaki, 1995; Moore, 1995).

The lithography process used in semiconductor manufacturing is illustrated in figure 1 . There are three key component technologies that are integrated in the lithography process - the mask, the alignment equipment and the resist. The lithography process takes place when beams of ultraviolet (UV) light from the alignment equipment are directed onto the mask. The mask bears the blueprint of the DRAM chip design. Since the DRAM chip is made up of several stacked layers with each layer characterized by a unique circuit design, several unique masks are used to create a single DRAM chip. The mask allows a portion of the light to pass through, onto 
the semiconductor substrate. The substrate, a DRAM wafer, is coated with an energy sensitive chemical "resist". The resist undergoes a chemical reaction wherever the mask has allowed the light to pass through. This chemical reaction changes the structure of the resist and allows its selective removal from the wafer through a developing process. Another chemical process is then initiated in which the exposed parts of the wafer are etched. Finally, the remaining resist is removed, creating a final circuit that replicates the initial DRAM design. A typical DRAM chip goes through this process a number of times to sequentially build the integrated circuits with different mask designs. For example, the recent 128M DRAM chip went through as many as 120 lithography process steps.

(Insert Figure 1 about here)

The alignment equipment, the resist and the mask are key component technologies in the DRAM manufacturing vertical chain. The DRAM firm's commercialization of new generation depends in large part on progress in these component technologies. While all these technologies have been progressing at fast rates, their progress has not been uniform leading to the rise of technological bottlenecks (Kapoor and Adner, 2007). Moreover, the integration of these component technologies during the commercialization stage requires extensive experimentation and firm-specific learning. For example, a manager from a supplier of mask technology commented:

"We can offer our technology to our customer but how that technology works in the customer's facility is very much a function of how the customer integrates the different technologies and we typically go back and forth until the technology is implemented in production." 
Hence, DRAM firms are faced with significant challenges in coordinating the technological changes in the lithography components in order to commercialize the new generation.

\section{$\underline{\text { Component Technologies and Asset Specificity }}$}

The commercialization of the new DRAM generation requires close collaboration between personnel in the product design, process technology and manufacturing engineering groups within the DRAM firm. This close collaboration has been referred to as "unstructured technical dialog" which creates human asset specificity between the design and manufacturing activities (Monteverde, 1995). Since the mask represents the blueprint of the firm's product design and is used to develop and scale up the manufacturing process, it is the bridge through which this unstructured technical dialog takes place. Moreover, the mask activity is normally located in a very close proximity to the semiconductor manufacturing. This is due to the extensive timing and coordination during the commercialization of new DRAM innovation. Any delays in mask production can significantly affect the DRAM firm's ability to introduce the new generation, adversely affecting its competitive advantage. Hence, the coordination between mask making activity and DRAM production is also characterized by temporal specificity (Masten et al., 1991). Our interviews with industry experts confirmed this aspect of coordination. For example, a technical manager with a leading semiconductor manufacturer commented:

\footnotetext{
"From lab to production, there are typically three to four mask redesigns.....Your designers come to you and say we are going to change the chip design and you should be able to implement it [the new mask design] very quickly."
}

The commercialization process also includes extensive experimentation with different types of resist. The suitability of resist is evaluated based on its coating uniformity on the 
semiconductor substrate, its interaction with the alignment tool as well as its stability during the chemical processes of developing and etching. A DRAM manufacturer invests significant amount of effort and resources extending over many months in finalizing a resist for the new DRAM process. Once a particular resist is finalized in a firm's process "recipe", any changes are time consuming and extremely costly. In addition, DRAM firms invest in dedicated equipment for downstream processes in their manufacturing lines which may be specific to a given resist chemistry.

The alignment equipment is the final component technology within the lithography architecture. As with resist, firms invest significant resources in selecting the alignment equipment from a limited number of suppliers. In addition, firms incur dedicated investments to integrate the equipment into their manufacturing lines and to create the infrastructure for maintenance.

\section{Component Technologies and Firm Boundaries}

The above discussion suggests that all three lithography component technologies exhibit a high degree of asset specificity for a DRAM firm during the commercialization of new generation and hence, DRAM firms may be subjected to contractual hazards from the suppliers

of the respective components. While transaction cost considerations may suggest that an efficient organization of activities would constitute firms internalizing all the three components, firm's choice may also depend on consideration of production costs and firm capabilities (e.g., Walker and Weber, 1984; Argyres, 1996). During the time period that we studied, some DRAM firms integrated the production of mask but no firm integrated the production of resist or the alignment equipment. This finding is consistent with prior research. The development and production of 
resist requires large $\mathrm{R} \& \mathrm{D}$ and production investments, and a deep knowledge of chemical compounds and processing. Therefore, only large specialized chemical suppliers such as Kodak, Hoechst and Shipley have manufactured the resist for semiconductor manufacturing. These specialized chemical firms also enjoy large economies of scope through participation in other chemical markets. Similarly, the development and production of alignment equipment also require enormous $R \& D$ expenditures, and advanced knowledge of optics and mechanics. Hence, firms such as Perkin Elmer, Nikon and Canon with superior optics and mechanics capabilities, and participation in multiple photo-imaging markets have supplied the alignment equipments to DRAM firms.

While DRAM firms did not integrate the production of key components, we found that they invested in the knowledge of such components. As discussed later, our examination of patents filed by DRAM firms showed that these firms invested in the knowledge of components even when they outsourced their production. This finding is consistent with prior examination of knowledge boundaries using patent data for 440 of the world's largest firms (Patel and Pavitt, 1997) and for aircraft engine makers (Brusoni et al., 2001).

\section{DRAM Innovation and the Nature of Technological Change}

The capability of the lithography process is defined based on the minimum feature size the smallest circuit dimension that can be patterned on the semiconductor. Figure 2 plots the introduction of different DRAM generations and the minimum feature size in microns $\left(\mu \mathrm{m}=10^{-}\right.$

${ }^{6} \mathrm{~m}$ ) that is achieved through improvements in the lithography process. Since the emergence of the DRAM industry with the introduction of 1K DRAM, there have been a total of 12 new generations from 1974 to 2005 . Moreover, each generation is enabled by the DRAM firm's 
reduction of the minimum feature size. This reduction is largely attributed to progress in the alignment equipment, the resist and the mask.

(Insert Figure 2 about here)

While the new DRAM generations were commercialized through improvements in the alignment equipment, the resist, and the mask, there were differences in the nature of the technological changes across these generations. Table 2 lists the different DRAM generations, the minimum feature size and the key changes in the lithography technology that enabled the commercialization of the new product. We describe the details of these changes elsewhere (Kapoor and Adner, 2007). From the table, it can be seen that certain changes within the lithography technology represented incremental innovations whereas others represented architectural innovations (Henderson and Clark, 1990). For example, in the 64K DRAM innovation, there was a change in the lithography technology from proximity printing method to projection printing method. While projection printing technology promised smaller feature size and higher yield, it shifted the emphasis on the process yield from the alignment equipment to the mask. The change also altered the relationship between the mask and the alignment equipment as the optical energy from the alignment equipment was gradually scanned across the wafer after being projected through a lens system. In contrast, the commercialization of $1 \mathrm{M}$ DRAM was achieved through incremental changes in components within the same technology architecture as the previous generation of product.

(Insert Table 2 about here) 
The classification of these generations as being either incremental or architectural is a key aspect of this study and presented us with a major challenge. To obtain this classification, we discussed the details of each technology transition with a number of industry experts, read technical articles from the annual lithography conference organized by The International Society for Optical Engineering (SPIE) since 1976, and read articles written by industry analyst firms such as Integrated Circuit Engineering, VLSI Research and IC Knowledge. For each technology transition we characterized the changes in lithography technology that enabled the new DRAM generation. We also characterized the changes in the relationship in the linkages between the key components of aligner, mask, and resist. We tabulated these descriptions, circulated them among our industry experts, and made changes based on their feedback. All the experts agreed with our final characterization of the different DRAM generations. Consistent with the description of architectural innovation in Henderson and Clark (1990) and on the construct items developed by Gatignon et al. (2002), we identified the DRAM innovations being either incremental or architectural according to whether a technological generation entailed changes in the critical relationships among key components (coded architectural) or not (coded incremental).

While the successful DRAM generations have been either incremental or architectural, there have also been attempts to introduce radical innovations to replace the conventional integrated circuit technology based on the metal-oxide-semiconductor (MOS) technology. ${ }^{4}$ However, none of the radical innovations have entered the mainstream of DRAM markets and hence, this setting provides us with a natural control for innovations that are, exclusively, either incremental or architectural.

\footnotetext{
${ }^{4}$ These include the development of various magnetic memory products such as the bubble memory and the magnetoresistive random access memory (MRAM) that required very different processing technologies and materials.
} 


\section{Measures}

\section{Dependent Variable}

Our measure of firm performance is based on the firm's timing of commercialization of the new DRAM generation. Research in strategy has considered firm's time of entry into new markets as an important driver of competitive advantage (Lieberman and Montgomery, 1988; 1998). In addition, studies on innovation have used firm's timing of new innovation as a key measure of its performance (e.g., Schoonhoven et al., 1990; Brown and Eisenhardt, 1995; Gatignon et al., 2002). The sharp price erosion and intensive rivalry in the DRAM industry creates a significant early mover advantage within a given DRAM generation (Methe, 1992; Enz, 2003). These advantages are largely a result of learning by doing (Hatch and Mowery, 1998; Irwin and Klenow, 1994). As a result, DRAM firms are continuously striving to be first to introduce the new generation with improved lithography technology. The measure is also appropriate to test for the firm's ability to coordinate technological changes in its vertical chain so as to minimize delays in the commercialization of new innovations.

We measure the firm's Timing of Innovation as one plus the difference in the number of quarters (3-month periods) between the first shipment by the firm and the first shipment in the industry for a given DRAM generation. Hence, the first firm takes the value of 1 and a firm that commercializes the generation three quarters after the first firm takes a value of 4 . We used the logarithmic transformation of the dependent variable in our analyses. ${ }^{5}$ Since we examine all firms that have participated in the industry, we do not face any left censoring issues. We are also confident that right censoring is not a problem in our data given the dynamics of the industry. In

\footnotetext{
${ }^{5}$ As a test of robustness, we also used a linear specification and the results are fully consistent with those reported here, but with a lower R-squared.
} 
the DRAM industry, product life cycles are short and entry into older generation of products is not economically viable once a new product has taken root; that is, firms begin their production in the newly introduced generation, not the older ones). The only generation for which we have potentially incomplete observations is the $1 \mathrm{G}$ generation that emerged in 2003 , into which a number of incumbents had yet to enter by 2005 . We performed robustness test by excluding the $1 \mathrm{G}$ generation and the results are consistent with the ones reported here.

\section{$\underline{\text { Independent Variables }}$}

Among the three component technologies- the mask, the resist and the alignment equipment, we focus on the firm's governance choice (make-or-buy) decision for the mask technology and investment in knowledge for both the mask and the resist technology. As discussed earlier, none of the DRAM firms internalized the production of the resist due to the high cost of development and production and hence, we do not consider the governance choice for the resist. We also exclude the alignment equipment from the boundaries' analysis as there were no instances of internalized production and it was difficult to measure the knowledge of the alignment equipment using the patent data.

The industry has treated the mask and the resist technology as key component technologies for semiconductor manufacturing. The importance of the mask and the resist technology to the semiconductor industry can be exemplified by the occurrence of regular annual dedicated conferences such as Photomask Japan, the Annual BACUS Symposium, the European Conference on Mask Technology and Advances in Resist Technology and Processing in which new technological developments are presented and discussed. The variable Mask Governance takes a value of 1 if the DRAM firm outsourced the production of mask technology and takes the 
value of 0 if the firm is vertically integrated into the mask technology in the year prior to its commercialization of the new DRAM innovation. We measured the firm's knowledge in the mask and resist technology using patent data. We asked industry experts who have been associated with the mask and resist R\&D to provide us with the most prominent technology subclasses associated with the two components. ${ }^{6}$ We identified the patent subclass $430 / 5$ as the key technology subclass for the mask technology, and patent subclasses 430/270.1, 430/191a, 430/192a, 430/326, 430/325, 430/281.1, 430/190, 430/311 as key technology subclasses for the resist technology. We also confirmed the validity of the subclasses as proxy for knowledge underlying the components by examining the patents granted to specialized mask and resist manufacturers. The subclasses mentioned above dominated the patents for all specialized firms. The variables Mask Knowledge and Resist Knowledge are operationalized as the number of mask and resist related patents filed by the DRAM firm within the 3 years preceding the firm's year of commercialization of the new DRAM generation. Similar patent based measures have been used in prior studies to examine firm's knowledge in a given technology (e.g., Patel and Pavitt, 1997; Cattani, 2005). We defined the variable Architectural Innovation for a DRAM generation based on whether the generation entailed changes in the linkages among the key components as indicated in table 2. The variable takes a value of 1 if the DRAM innovation is architectural and 0 if it is incremental.

\section{Control Variables}

We controlled for Firm Size as measured by the log of firm's annual sales (in millions of $\$$ ) in the year prior to its commercialization of the new generation. Firms in our sample vary in

\footnotetext{
${ }^{6}$ These experts included industry veterans such as Marc Levenson, who worked for IBM during the 1980's and is the inventor of perhaps the most important innovation in the mask technology - the phase shift mask, that allowed for feature sizes to be smaller than $0.25 \mu \mathrm{m}$.
} 
their degree of dependence on the DRAM market. Besides DRAMs, these firms may also be active in other semiconductor markets. Burgelman's (1994) account of Intel's participation in both the DRAM and the microprocessor markets suggested that firm's market scope may influence its resource allocation towards the development of new innovations. We controlled for this effect using the variable Firm Scope, defined as the percentage of firm's sales in non-DRAM markets in the previous year. Finally, we account for variations in the complexity of the DRAM innovation. The variable DRAM Feature Size, the smallest dimension of the circuit, is a widely used measure of the sophistication of the product and the process technology required to create these miniaturized DRAM products.

As a robustness check, we also controlled for Japanese firms and the results are consistent with the ones reported in the paper. Evidence, primarily from the automotive industry, have shown that Japanese firms use greater degree of relational governance that increases trust and decreases opportunism (e.g., Womack, Jones and Roos, 1990; Dyer, 1997). However, as noted by Williamson (1985) and more recent evidence by Ahamdjian and Lincoln (2001), Japanese auto firms use a combination of formal and relational contracts to manage governance in the vertical chain. While Japanese firms may face reduced opportunism, governance of supplier activities is certainly a key determinant of their success and this governance capability has been shown to increase with their knowledge of supplier activities (e.g., Takeishi, 2002).

Finally, to ensure that our results are not biased by temporal effects, we created dummy controls for each of the four decades in our study - although we would have preferred to use finer grained temporal controls, we are constrained by the degrees of freedom in our data. The results with time controls are fully consistent with the ones reported here. 


\section{Statistical Method and Analysis}

Since firms may self-select into the governance form, it is possible that the observed level of performance is conditional upon unobserved factors that may have influenced the firm's governance choice (e.g., Leiblein et al., 2002). Unobserved factors that influence both the governance form and performance thus create a selection bias and normative implications drawn from the estimation are incorrect. We follow Heckman procedure (1979) to address this selfselection problem. This procedure includes a first-stage probit model to specify a selection equation and then calculates the inverse Mill's ratio $(\lambda)$ that is used as a control variable in the second stage performance model (cf. Shaver, 1998). The first stage selection equation is given by:

$$
\operatorname{Prob}\left(Y_{i}=1 \mid X_{i}\right)=\Phi\left(\delta^{\prime} X_{i}\right)
$$

Where $Y_{i}$ is governance choice variable that takes the value of one if a firm outsources the production of mask and zero if it vertically integrates into the mask. The set of independent variables includes measures for firm's production economies and knowledge in mask, the extent of new technology investment required in the mask to commercializing the new DRAM generation and the contractual hazards associated with the existing mask supply. Firm characteristics include production scale measured through firm size, production scope measured through firm scope and mask knowledge. We also consider the extent of new technology investment that firms may incur in mask for the new DRAM generation. The need for new investment may prevent firms from vertical integration (Balakrishnan and Wernerfelt, 1986). The DRAM feature size is a useful proxy to measure the degree of new investment as smaller feature size significantly increases firm's investments in the mask making facility (Trybula and Grenon, 2003). Finally, we use the number of mask suppliers as an instrument in the first-stage estimation. Prior research has identified small numbers bargaining hazards due to the number of 
suppliers as being an important source of contractual hazards that firms may consider in choosing their governance mode (Pisano, 1990; Leiblein et al., 2002). We account for this hazard by measuring the number of mask suppliers in the given year of observation.

After the first stage estimation for firm's governance choice and the calculation of the inverse Mill's ratio $(\lambda)$, the second stage performance model is estimated using ordinary least squares (OLS). Since firms participate in multiple DRAM generations, we account for the possibility that residuals for a given firm may be correlated across innovations by using STATA's “cluster" option.

\section{RESULTS}

\section{First-Stage Governance Choice Results}

Table 3 presents results from the first stage governance choice models for mask $(\mathrm{Buy}=1$, Make=0). In model 1, we include the direct effects of firm attributes - firm size, firm scope and mask knowledge. In model 2, we test the effect of new technology investment by including DRAM feature size and in model 3, the full model, we test the effects of small numbers bargaining hazards by including the number of mask suppliers. The results from all specifications are consistent with previous research. The decision to internalize the production of mask technology is based on firms' consideration of both production and transaction costs (Williamson, 1985: 93). The coefficient for firm size is negative and significant suggesting that large firms are more likely to vertically integrate into mask. As expected, the coefficient for firm scope is negative indicating that firms that are also active in other non-DRAM markets have a greater propensity to vertically integrate. Firms are more likely to undertake large investments in mask production if they can leverage this strategic asset for DRAMs as well as other markets. 
However, this effect is significant for only models 1 and 2. The effect of mask knowledge is positive and weakly significant for models 1 and 3 suggesting that firms with greater mask knowledge are more likely to use external governance. The coefficient for DRAM feature size is negative and significant suggesting that as the degree of investment in mask production increases, firms tend to rely on external suppliers for their masks. Finally, the positive and significant coefficient for number of suppliers is consistent with the expectation that firms internalize the production of mask when small numbers bargaining hazards are likely (Pisano, 1990; Leiblein et al., 2002). We use the results from model 3 to calculate the inverse Mill's ratio for the second-stage performance model.

(Insert Table 3 about here)

\section{Second-Stage Performance Results}

Industry incumbents pioneered all new technology generations in our study sample, regardless of whether the innovation was incremental or architectural. Moreover, in 10 out of 12 generations (the exceptions are $4 \mathrm{~K}$ and $128 \mathrm{M}$ ), the pioneering incumbents were vertically integrated with respect to the mask technology. Therefore, vertical integration of mask seems to facilitate early commercialization of the DRAM generation. The descriptive statistics and correlations for variables used in the second stage model are reported in table 4.

(Insert Table 4 about here) 
Table 5 provides results from the firm's performance model. Model 1 includes the controls and the firm's knowledge and governance choice for mask. In model 2, we account for the potential self selection bias in the choice of governance mode by including the inverse Mill's ratio. In model 3, we relax the assumption that the coefficients for firms that are vertically integrated are the same as the firms that outsource the mask technology. Controlling for self selection, we split our sample between vertically integrated and non-integrated firms and estimate their effects separately. In model 4 we include the effect of firm's resist knowledge and in model 5 we include the covariate for architectural innovation.

A comparison of the results of model 2 with those of model 1 indicates that the coefficients are broadly similar in signs and magnitude except with generally larger standard errors. The statistically significant coefficient for the inverse Mill's ratio justifies the use of the Heckman procedure in our performance estimation. The coefficient for mask governance is positive and significant suggesting that firms that do not integrate into mask production tend to commercialize new generations later than their vertically integrated rivals, even after controlling for the unobserved characteristics that may influence both the firm's governance choice and performance. Hence, these results support hypothesis 1.

(Insert Table 5 about here)

In model 3, the coefficient for mask knowledge is negative and significant not only for firms that integrate into mask production but also for firms that outsource the mask. This implies that firms that do not integrate into mask production can offset their disadvantage by investing in mask knowledge to improve their ability to coordinate technological changes in the vertical 
chain (Hypothesis 2). The difference in the mask knowledge coefficient for the firms that vertically integrate into mask and those that do not was statistically insignificant $(\mathrm{p}=0.644)$.While both integrated and non-integrated firms benefit from their knowledge of masks, the estimated coefficient for resist knowledge is negative and significant only for firms that do not integrate into mask. Whereas non-integrated firms benefit from their knowledge of both the resist and the mask, firms that integrate into mask do not benefit from their knowledge of resist. Hence, the effect of resist knowledge on the firm's timing of innovation provides mixed support for hypothesis 2. Moreover, the difference in the resist knowledge coefficient between the two subsamples is significant $(\mathrm{p}=0.039)$ suggesting that non-integrated firms benefit more from their knowledge of resist than do firms that integrate into mask.

In model 5, the coefficient for architectural innovation is negative but insignificant for integrated firms. The effect is positive and significant for non-integrated firms. Hence, nonintegrated firms tend to commercialize the new DRAM generation later when the change is architectural than when it is incremental. In contrast, vertically integrated firms seem unaffected by the nature of the transition. The findings from model 5 support hypothesis 3 that the negative effect of non-integration on the firm's performance is greater during an architectural change than during an incremental change. We also find that the difference between the two coefficients is significant $(\mathrm{p}=0.025)$ which implies that the detrimental effect of architectural innovation is greater for non-integrated firms than for integrated ones.

In order to better interpret the above findings, Figure 3 plots the expected timing of new DRAM generation for an average firm as a function of the firm's mask and resist knowledge for the different governance choices and the transition types. We generate the figure by multiplying the coefficient estimates with the average firm attributes for the respective integrated and non- 
integrated sub-samples. At the mean levels of mask and resist knowledge, a firm that integrated into mask commercializes the new innovation 2.31 quarters after the first introduction and this timing is independent of whether the innovation is incremental or architectural. At the mean level of mask and resist knowledge, the non-integrated firms commercialize the new innovation 4.76 quarters after the first introduction when the innovation is incremental and 7.32 quarters after the first introduction when the innovation is architectural. A one standard deviation increase in the non-integrated firm's mask and resist knowledge reduces the lag to 2.74 quarters in the case of an incremental innovation and 4.39 quarters in the case of an architectural innovation. In assessing the economic significance of these commercialization lags, consider that the average quarterly market size during the first two years of the 64M DRAM was US\$497m. In addition to extracting greater share of this revenue, early commercialization may also provide a firm with a significant competitive advantage through learning by doing which carry over into later time periods (Irwin and Klenow, 1994).

\section{(Insert Figure 3 about here)}

We performed several additional tests to ensure that our reported results are not sensitive to the chosen measures. It is possible that the first shipment may represent delivery of samples that may not be fully qualified by the customers. Hence, the quarter in which the first shipment is recorded for the new DRAM innovation may inappropriately confer an early "sampler" with a competitive advantage. In order to check for this bias, we also tested two alternative commercialization thresholds in which the timing of innovation was measured as the first quarter in which the firm shipped 100,000 and 250,000 units of the new DRAM generation. In addition, 
we also included a 5-year window for the patent based measures of component knowledge. Finally, as the primary subclass may under-represent the knowledge underlying the patent granted to the firm, we included component knowledge measures using patents where the mask or the resist subclass is not restricted to only the primary subclass. The results from all the above alternative measures were fully consistent with the ones reported in the paper.

Lastly, we comment on the results for the control variables. After accounting for governance selection, the estimated effect for firm size is insignificant. The effect of firm scope is positive and significant for both the integrated and non-integrated firms suggesting that broader firm scope could compromise the speed of the firm's new DRAM technology development as resources get shared across multiple product lines. As expected, the effect of DRAM feature size is negative. However, it is significant only for non-integrated firms. Greater complexity of the DRAM (smaller feature size) is correlated with greater delays in the nonintegrated firms' commercialization of the new DRAM generation. The difference between the coefficients for integrated and non-integrated firms was insignificant $(\mathrm{p}=0.956)$.

\section{DISCUSSION AND CONCLUSIONS}

This study examines how firms' vertical scope, measured through both production and knowledge boundaries, affects their performance during periods of technological change. While prior research on innovation has focused on the internal challenges faced by firms, we explicitly add consideration of the external challenges in coordinating technological changes in the vertical chain. We suggest that in the context of interdependent component technologies being integrated by the innovating firm, governance of activities in the vertical chain is a key determinant of the firm's ability to commercialize new innovations. 
We find support for prior research on production boundaries that firms' decision to integrate activities in the vertical chain is jointly determined by their capabilities, production and transaction costs. After taking into account the determinants of firms' governance choices, we find firms that integrate into components with high asset specificity are able to commercialize new innovations earlier than their non-integrated rivals. We also find that while high production costs may deter firms from internalizing the production of components with high transaction costs, firms' knowledge of such components can serve as an imperfect substitute to improving their commercialization of new innovations. This finding was validated in our conversations with industry participants who emphasized the importance of knowledge of the key lithography components in managing suppliers. For example, a technical manager with a large DRAM manufacturer remarked:

"If we were to just get the resist from the market without having any expertise, it will be a disaster for developing the new technology...... this knowledge is just not useful but essential, and an important source of competitive advantage."

The knowledge of upstream components is likely to facilitate the firm's governance of activities in the vertical chain during their development and integration into the firm's product. We discussed this result with a manager in a non-integrated firm and he commented:

\footnotetext{
"The expertise in resist and mask helps us to select suppliers but more importantly, it helps us to manage the ongoing process of evaluation and feedback with the supplier during technology development iterations... expertise in mask and resist helps you to design contracts....in most companies, the actual people that do purchasing work very closely with engineers to create specifications when they create contracts....the last two [monitoring and writing of contracts] are more important aspects and gives more bang for your buck for investment in expertise."
}

A surprising result from the study was that firms' knowledge of external components with high asset specificity seems to play a more significant role for lean firms - those that do not 
vertically integrate into either of the components, but does not affect the performance of firms that vertically integrate into the mask. Why is it that a firm that does not integrate into any of the components of lithography technology benefits more from knowledge of external components than a firm that "partially" integrates into the technology? We asked this question of our industry experts and the following quote captures the essence of the difference:

\footnotetext{
"Firms that outsource critical technologies have more incentive to develop supplier capabilities than firms that own technologies.....You do see [in the industry] that certain firms are much better in managing technology development with suppliers than others. These are the firms that rely on suppliers for most of their technology needs."
}

This finding certainly warrants future research in understanding how the scope of firm's vertical integration in a multi-component technology interacts with its knowledge of components to influence governance capabilities and competitive advantage. It is possible that non-integrated firms may build superior capabilities to manage suppliers and enjoy greater benefits from their knowledge of external components. The increasing diversity of component technologies and their rapid rate of change are making it increasingly difficult for all critical components to be produced within a single firm (e.g., Freeman, 1991; Fine, 1998). Hence, firms' governance capabilities are likely to play a critical role in their successful commercialization of new innovations.

The final result of the study shows that within the existing vertical chain of activities, incremental changes in component technologies result in changes in the interactions between components, and such architectural changes seem to create significant delays in the commercialization efforts of non-integrated firms. Hence, vertically integrated firms seem better suited for architectural innovations. This finding suggests an important boundary condition for firms pursuing non-integrated "lean" strategies that they may be significantly disadvantaged if 
new innovations are architectural. A corollary of this finding is that the lack of vertical integration in an industry may induce technological progress primarily through incremental innovations until a new radical innovation is introduced. ${ }^{7}$ Hence, architectural innovations which have a potential to extend the technology life-cycle may not be pursued due to coordination problems.

A separate issue concerns the general emphasis of research on innovation. Historically, the innovation literature has focused on understanding differences between entrants and incumbents during periods of punctuated technological change. While such episodes are both interesting and important, by far the bulk of economic activity is characterized by innovation and competition in an environment in which incumbents compete with other incumbents across nonradical technological transitions. Leading technology innovators such as Apple, IBM, Intel, General Electric, Microsoft, Samsung, Sony and Toyota are continuously faced with the challenge of introducing new innovations that improve the product performance or reduce cost within an existing dominant design. The timely commercialization of these innovations plays an important role in extending the firms' competitive advantage over their rivals. For example, the results from a recent survey of more than 1000 senior managers by BusinessWeek and the Boston Consulting Group revealed incumbents are spending the largest percentage of their innovation related resources on non-radical innovations and the biggest obstacle cited towards realizing the returns on investments in innovation was slow development times (BusinessWeek, 2006). We hope that the findings of this study would encourage scholars in innovation to move beyond the "incumbent vs. entrant" question to also consider the drivers of the "incumbent vs. incumbent" competitive advantage during periods of non-radical technological change.

\footnotetext{
${ }^{7}$ Economic historians have documented a relationship between the extent of vertical integration in an industry and its rate and direction of technological advance. For example, see Frankel's account of innovations in the British textile and iron and steel industries (1955) and Marx's account of the diesel-electric locomotive industry (1976).
} 
While we have taken care in this empirical examination, there are several limitations. The sample is restricted to a single industry and there is a need to explore the generalizability of our findings in other contexts. Our use of patent data to measure firm's component knowledge assumes the firm's propensity to disclose such knowledge. It is possible that certain DRAM firms may choose to keep this knowledge as a trade secret. However, there is strong evidence that semiconductor firms aggressively patent to use their knowledge as bargaining chips (Hall and Ziedonis, 2001), such that our context at least partially controls for this concern. Finally, although our measure of innovation performance as firm's timing of DRAM innovation is particularly suitable to our context, it would be of interest to explore our hypothesized effects using additional measures of performance.

Overall, the results of the study argue that the effect of technological change on firms should be considered more broadly to also include technological changes in the firm's vertical chain. We show that governance issues are no less important than firm's internal resources and routines in managing technological changes that underlie the commercialization of new innovation. Moreover, we hope that our results encourage researchers to expand their examination of governance strategies pursued by firms beyond the make-or-buy to also include their knowledge profiles, and consider how these strategies interact with changes in technology. This study also extends the emerging literature that integrates transaction cost economics with competence based perspectives (Argyres, 1996; Leiblein and Miller, 2003; Jacobides and Hitt, 2005; Hoetker, 2005; Mayer and Salomon, 2006). We show how firms' governance decisions and knowledge affect a different performance outcome than those normally looked at - firms' timing of new innovation. We also show that while firms' knowledge of external activities may 
facilitate the development of governance capabilities, its effect may be muted for firms that are

integrated into a subset of activities and have a lower reliance on external suppliers.

\section{REFERENCES}

Abernathy, W. J., and Utterback, J. M. 1978. Patterns of Industrial Innovation. Technology Review, June/July 1978: 40-47

Adner, R. 2006. Match Your Innovation Strategy to Your Innovation Ecosystem. Harvard Business Review, 84(4): 98-107.

Adner, R., \& Kapoor, R. 2006. Innovation Ecosystems and Innovator Outcomes: Evidence from the Semiconductor Lithography Equipment Industry, 1962-2004. INSEAD Working Paper.

Afuah, A. N., \& Bahram, N. 1995. The Hypercube of Innovation. Research Policy 24: 51-76

Afuah, A. 2001. Dynamic Boundaries of the Firm: Are Firms Better off Being Vertically Integrated in the Face of a Technological Change? The Academy of Management Journal, 44(6): 1211-1228.

Ahmadjian, C. L., \& Lincoln, J. R. 2001. Keiretsu, Governance, and Learning: Case Studies in Change from the Japanese Automotive Industry. Organization Science, 12(6): 683-701.

Anderson, P. C., \& Tushman, M. L. 1990. Technological discontinuities and dominant designs. Administrative Science Quarterly, 35(4): 604-633.

Argyres, N. 1996. Evidence on the role of firm capabilities in vertical integration decisions. Strategic Management Journal, 17: 129-150.

Argyres, N., \& Mayer, K. J. 2007. Contract Design as a Firm Capability: An Integration of Learning and Transaction Cost Perspectives. Academy of Management Review, 32(4).

Balakrishnan, S., \& Wernerfelt, B. 1986. Technical change, competition and vertical integration. Strategic Management Journal, 7(3): 347-359.

Brown, S \& Eisenhardt, K. 1995. Product development: Past research, present findings and future directions. Academy of Management Review 20: 343-378.

Brusoni, S., Prencipe, A., \& Pavitt, K. 2001. Knowledge Specialization, Organizational Coupling, and the Boundaries of the Firm: Why Do Firms Know More Than They Make? Administrative Science Quarterly, 46(4): 597-621.

Burgelman, R. A. 1994. Fading memories: A process theory of strategic business exit in dynamic environments. Administrative Science Quarterly, 39(1): 24-56.

BusinessWeek. 2006. The World's Most Innovative Companies. http://www.businessweek.com/magazine/content/06_17/b3981401.htm

Cattani, G. 2005. Preadaptation, Firm Heterogeneity, and Technological Performance: A Study on the Evolution of Fiber Optics, 1970--1995. Organization Science, 16(6): 563-580.

Chesbrough, H. W., \& Teece, D. J. 2002. Organizing for Innovation: When Is Virtual Virtuous? Harvard Business Review, 80(8): 127-135.

Chesbrough, H.W., 2001. Assembling the elephant: a review of empirical studies on the impact of technical change upon competing firms. In: Burgleman, R., Chesbrough, H.W.(Eds.) Comparative Technological Evolution: Towards a Global Understanding of Innovation, Research on Technological Innovation, Management and Policy, Vol. 7. Elsevier, Amsterdam.

Christensen, C. M. 1992. Exploring the Limits of the Technology S-Curve. Part I: Component Technologies. Production and Operations Management, 1(4): 334-357.

Christensen, C. M. 1993. The Rigid Disk-Drive Industry - A History Of Commercial And Technological Turbulence. Business History Review, 67(4): 531-588. 
Christensen, C. M., \& Rosenbloom, R. S. 1995. Explaining the attacker's advantage: Technological paradigms, organizational dynamics, and the value network. Research Policy, 24(2): 233-257.

Christensen, C. M. 1997. Innovator's Dilemma: When New Technologies Cause Great Firms to Fail. Boston: Harvard Business School Press.

Christensen, C. M., Verlinden, M., \& Westerman, G. 2002. Disruption, Disintegration, and the Dissipation of Differentiability. Industrial \& Corporate Change, 11(5): 955-993.

Cooper, A. C., \& Schendel, D. 1976. Strategic Response to Technology Threats. Business Horizons, 19(1): 61-69.

Dosi, G. 1982. Technological Paradigms and Technological Trajectories. Research Policy, 11: 147-162.

Dyer, J. H., 1997. Effective interfirm collaboration: how firms minimize transaction costs and maximize transactional value. Strategic Management Journal 18 (7): 535-56

Dyer, J. H., \& Nobeoka, K. 2000. Creating and Managing a High-Performance Knowledge-Sharing Network: The Toyota Case. Strategic Management Journal, 21(3): 345-367.

Enz, M. J. 2003. Estimates of first-mover advantages in markets with relatively short product life cycles: An examination of the DRAM industry. Ph.D. Thesis. University of Oregon

Fine, C. H. 1998. Clockspeed: Winning industry control in the age of temporary advantage. Reading, MA: Perseus Books.

Frankel, M. 1955. Obsolescence and Technological Change in a Maturing Economy. American Economic Review 45: 296-319

Freeman, C. 1991. Networks of innovators: A synthesis of research issues. Research Policy, 20(5): $499-514$.

Gatignon, H., Tushman, M. L., Smith, W., \& Anderson, P. 2002. A Structural Approach to Assessing Innovation: Construct Development of Innovation Locus, Type, and Characteristics. Management Science, 48(9): 11031122.

Gawer,A., \& Henderson,R. 2007. Platform owner entry and innovation in complementary markets. Journal of Economics and Management Strategy, 16(1): 1-34.

Hall, B. H., \& Ziedonis, R. H. 2001. The Patent Paradox Revisited: An Empirical Study of Patenting in the U.S. Semiconductor Industry, 1979-1995. Rand Journal of Economics, 32(1): 101-128.

Hatch, N. W., \& Mowery, D. C. 1998. Process Innovation and Learning by Doing in Semiconductor Manufacturing. Management Science, 44(11): 1461-1477.

Heckman, J. J. 1979. Sample Selection Bias as a Specification Error. Econometrica, 47(1): 153-162.

Henderson, R. M., 1988. The Failure of Established Firms in the Face of Technical Change: A Study of Photolithographic Alignment Equipment. Ph.D. Thesis, Harvard University.

Henderson, R. M., \& Clark, K. B. 1990. Architectural innovation: The reconfiguration of existing product technologies and the failure of established firms. Administrative Science Quarterly, 35(1): 9-30.

Henderson, R. 1995. Of life cycles real and imaginary: The unexpectedly long old age of optical lithography. Research Policy, 24(4): 631-643.

Hoetker, G. 2005. How Much You Know Versus How Well I Know You: Selecting a Suppliers for a Technically Innovative Component. Strategic Management Journal, 26(1): 75-96.

Hughes, T. P. 1983. Networks of Power: Electrification in Western Society 1880 - 1930. Baltimore: Johns Hopkins University Press.

Iansiti, M. 1998. Technology Integration. Harvard Business School Press, Boston, MA

Irwin, D. A., \& Klenow, P. J. 1994. Learning-by-Doing Spillovers in the Semiconductor Industry. Journal of Political Economy, 102(6): 1200-1227.

Jacobides, M. G., \& Hitt, L. M. 2005. Losing Sight of the Forest for the Trees? Productive Capabilities and Gains from Trade as Drivers of Vertical Scope. Strategic Management Journal, 26(13): 1209-1227.

Johnson, D. W., \& Mack, C. A. 1992. I-line, DUV, VUV, or x ray? Proceedings of the International Society for Optical Engineering, 1674: 486-498. 
Kapoor, R. and Adner, R. 2007. Technology Interdependence and the Evolution of Semiconductor Lithography. Solid State Technology 50(11): 51-54.

Leiblein, M. J., \& Miller, D. J. 2003. An Empirical Examination of Transaction- and Firm-Level Influences on the Vertical Boundaries of the Firm. Strategic Management Journal, 24(9): 839.

Leiblein, M. J., Reuer, J. J., \& Dalsace, F. 2002. Do Make or Buy Decisions Matter? The Influence of Organizational Governance on Technological Performance. Strategic Management Journal, 23(9): 817-833.

Lieberman, M. B., \& Montgomery, D. B. 1988. First-mover advantages. Strategic Management Journal, 9: 41-58.

Lieberman, M. B., \& Montgomery, D. B. 1998. First-mover (dis)advantages: Retrospective and link with the resource-based view. Strategic Management Journal, 19(12): 1111-1125.

Macher J.T. 2006. Technological Development and the Boundaries of the Firm: A Knowledge-Based Examination in Semiconductor Manufacturing. Management Science, 52(6): 826-843.

Marx, T. 1976. Vertical Integration in the Diesel-Electric Locomotive Building Industry: A Study in Market Failures. Nebraska Journal of Economics and Business, 15(4): 37-51.

Masten, S. E., Meehan, J. W., \& Snyder, E. A. 1991. The Costs of Organization. Journal of Law, Economics, and Organization, 7(1): 1-25.

Masten, S. E. (Ed.). 1996. Case Studies in Contracting and Organization. New York: Oxford University Press.

Mayer, K. J., \& Salomon, R. M. 2006. Capabilities, Contractual Hazards, and Governance: Integrating ResourceBased and Transaction Cost Perspectives. Academy of Management Journal, 49(5): 942-959.

Methe, D. T. 1992. The Influence of Technology and Demand Factors on Firm Size and Industrial Structure in the DRAM Market - 1973-1988. Research Policy, 21(1): 13-25.

Monteverde, K. 1995. Technical Dialog As an Incentive for Vertical Integration in the Semiconductor Industry. Management Science, 41(10): 1624-1638.

Monteverde, K. M., \& Teece, D. J. 1982. Supplier Switching Costs and Vertical Integration in the Automobile Industry. Bell Journal of Economics, 13(Spring): 206-213.

Moore, G. E. 1995. Lithography and the Future of Moore's Law. Proceedings of the International Society for Optical Engineering, 2438: 2-17.

Mowery, D.C. 1983. The relationship between intrafirm and contractual forms of industrial research in American manufacturing, 1900-1940. Explorations in Economic History, 20:351-374.

Okazaki, S. 1995. Lithography for ULSI. Proceedings of the International Society for Optical Engineering, 2438: $18-32$.

Patel, P., \& Pavitt, K. 1997. The technological competencies of the world's largest firms: Complex and pathdependent, but not much variety. Research Policy, 26(2): 141-156.

Pisano, G.P. 1990. The R\&D Boundaries of the Firm: An Empirical Analysis. Administrative Science Quarterly, 35: $153-176$

Rosenberg, N. 1976. Perspectives on Technology. Cambridge: Cambridge University Press.

Rosenberg, N. 1982. Inside the Black Box: Technology and Economics. Cambridge, UK: Cambridge University Press.

Sahal, D. 1981. Patterns of Technological Innovation. Addison-Wesley, Reading, MA.

Schoonhoven, C., Eisenhardt, K., \& Lyman, K. 1990. Speeding Products to Market: Waiting Time to First Product Introduction in New Firms. Administrative Science Quarterly, 35: 177-207.

Shaver, J. M. 1998. Accounting for Endogeneity When Assessing Strategy Performance: Does Entry Mode Choice Affect FDI Survival? Management Science, 44(4): 571-585.

Takeishi, A. 2002. Knowledge Partitioning in the Interfirm Division of Labor: The Case of Automotive Product Development. Organization Science, 13(3): 321-338.

Teece, D. J. 1986. Profiting from Technological Innovation: Implications for Integration, collaboration, Licensing and Public Policy. Research Policy, 15(6): 285-305. 
Teece, D. J. 1996. Firm Organization, Industrial Structure, and Technological Innovation. Journal of Economic Behavior and Organization, 31: 193 - 224.

Tripsas, M. 1997. Unraveling the Process of Creative Destruction: Complementary Assets and Incumbent Survival in the Typesetter Industry. Strategic Management Journal, 18(6): 119-142.

Trybula, W. \& Grenon, B. J. 2003. Does technology acceleration equate to mask cost acceleration? Proceedings of the International Society for Optical Engineering: 93-99

Tushman, M. L., \& Anderson, P. 1986. Technological Discontinuities and Organizational Environments. Administrative Science Quarterly, 31(3): 439-465.

Walker, G., \& Weber, D. 1984. A transaction cost approach to make-buy decisions. Administrative Science Quarterly, 29(3): 373-391.

Wheelwright, S. C., \& Clark, K. B. 1992. Revolutionizing Product Development: Quantum Leaps in Speed, Efficiency, and Quality. New York: The Free Press.

Williamson, O. E. 1985. The economic institutions of capitalism: firms, markets, relational contracting. New York, London: Free Press, Collier Macmillan.

Williamson, O. E. 1991. Comparative Economic Organization: The Analysis of Discrete Structural Alternatives. Administrative Science Quarterly, 36: 269-296.

Womack, J. P., Jones, D. T. \& Roos, D. 1990. The machine that changed the world. New York: Rawson Associates. 
Figure 1

Schema of the Semiconductor Lithography Technology

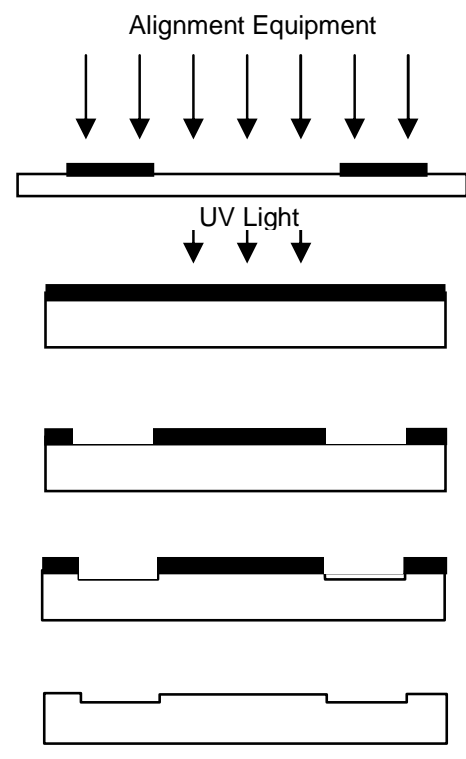

Mask with DRAM design on Top
DRAM wafer with a coat of Resist Layer

Selective Removal of Resist Layer

Etching of DRAM Wafer

Final Patterning of DRAM Wafer after Resist Removal

Figure 2

Introduction of New DRAM Generations, the Minimum Feature Size and Growth in the DRAM Market.

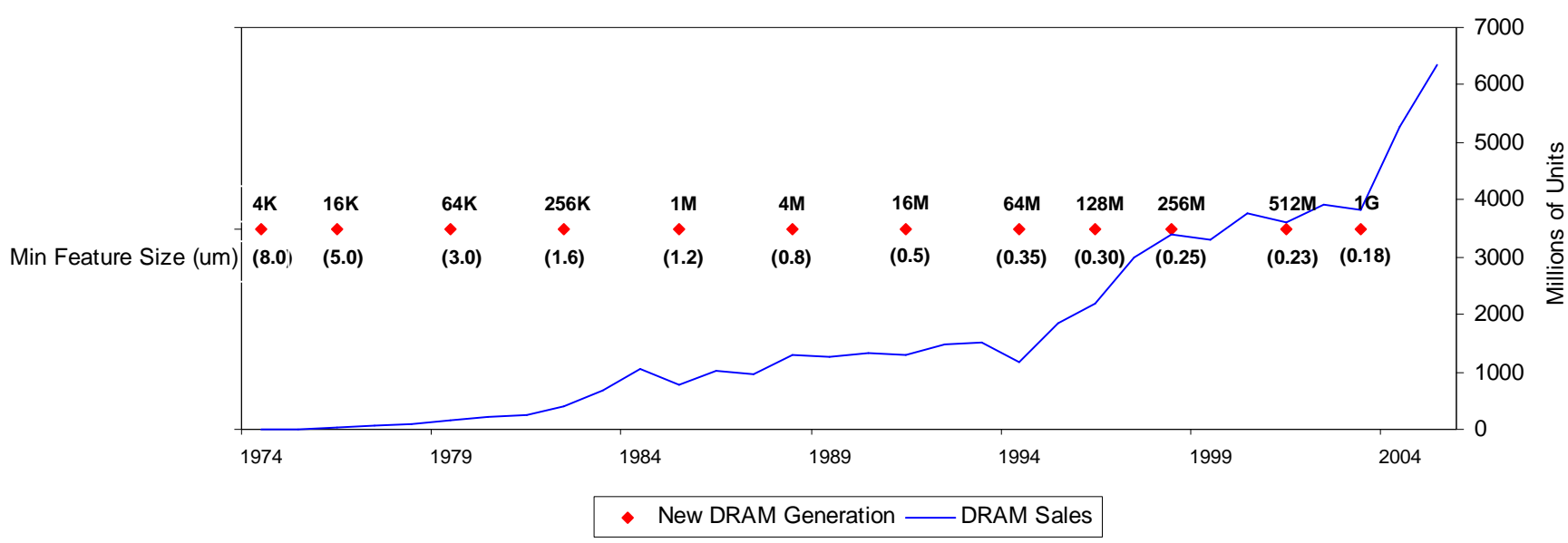




\section{Figure 3}

Firm's timing of DRAM innovation as a function of its governance strategy for mask, its knowledge of mask and resist, and the nature of technological change.
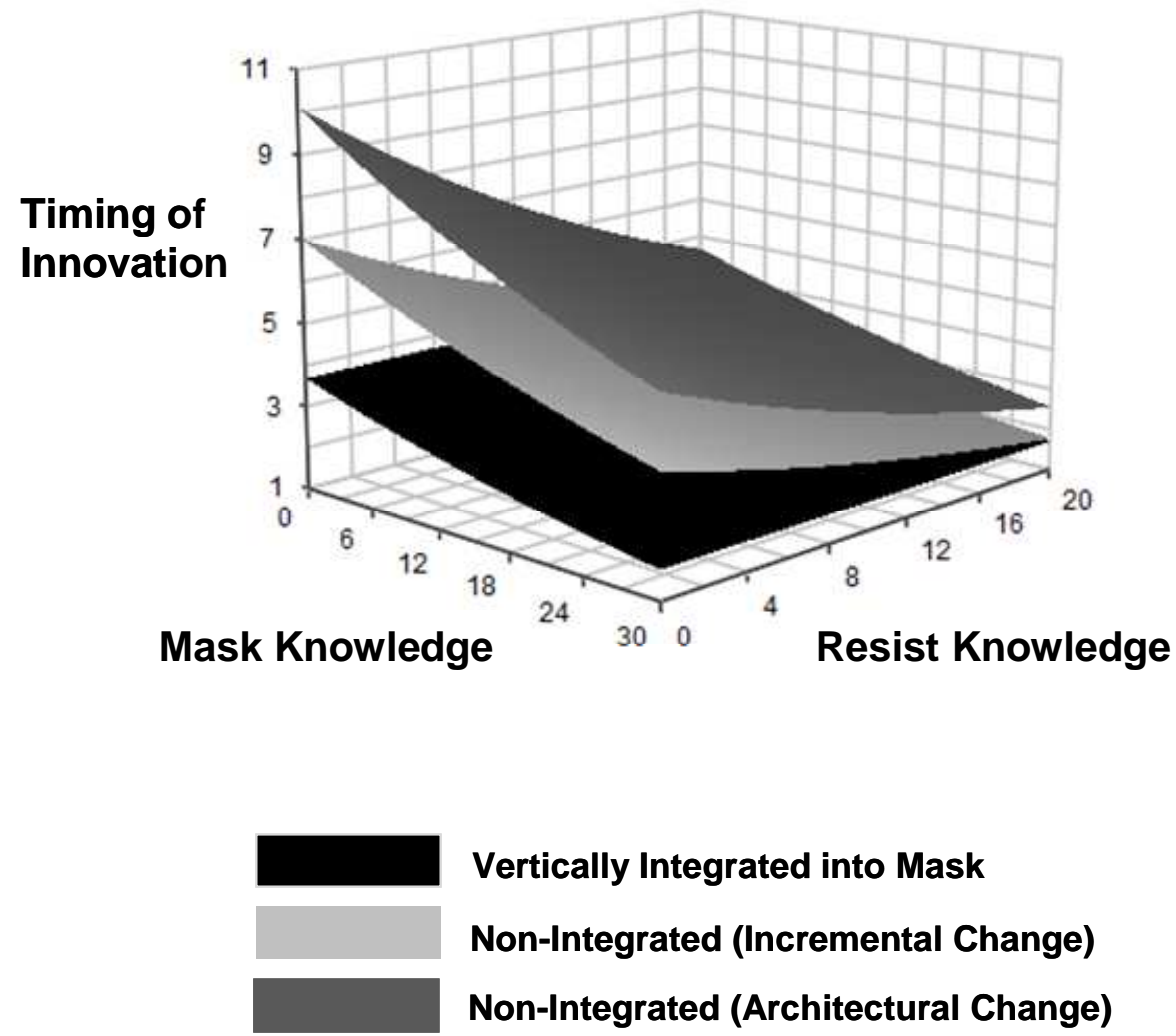

Vertically Integrated into Mask

Non-Integrated (Incremental Change)

Non-Integrated (Architectural Change) 
Table 1

Description of the Secondary Data Used for the Study

\begin{tabular}{|l|l|}
\hline Secondary Data Sources & Data \\
\hline Gartner Dataquest & $\begin{array}{l}\text { Quarterly DRAM shipment by } \\
\text { firm, Quarterly DRAM price. }\end{array}$ \\
\hline VLSI Research & DRAM firm annual sales. \\
\hline US Patent and Trademark Office & Patents granted to DRAM firms. \\
\hline Rose Reports & $\begin{array}{l}\text { DRAM firm's participation in } \\
\text { mask production. }\end{array}$ \\
\hline Reynolds Consulting & $\begin{array}{l}\text { DRAM firm's participation in } \\
\text { mask production. }\end{array}$ \\
\hline Grenon Consulting & $\begin{array}{l}\text { DRAM firm's participation in } \\
\text { mask production. }\end{array}$ \\
\hline IC Knowledge & DRAM feature size \\
\hline SPIE Conference Proceedings & $\begin{array}{l}\text { Changes in component } \\
\text { technologies of alignment } \\
\text { equipment, resist and mask for } \\
\text { DRAM generation. Changes in } \\
\text { relationships between different } \\
\text { components. }\end{array}$ \\
\hline Technical Articles) & $\begin{array}{l}\text { Changes in component } \\
\text { technologies of alignment } \\
\text { equipment, resist and mask for } \\
\text { each DRAM generation. }\end{array}$ \\
\hline
\end{tabular}

a We had to use multiple sources for the firm's make-or-buy decision for the mask technology as industry analysts providing such services operated at different time periods of the study. We used the overlapping years to check that the data between different sources is consistent. We found no discrepancy between the three sources. This is expected as internal mask production was a "commonly" known fact in the industry. 
Table 2

\section{Changes in Lithography Technology for Each DRAM Generation and the Nature of Technological Change}

\begin{tabular}{|c|c|c|c|c|}
\hline $\begin{array}{l}\text { DRAM } \\
\text { Generation } \\
\text { (Year) }\end{array}$ & $\begin{array}{l}\text { Minimum } \\
\text { Feature } \\
\text { size }(\mu \mathrm{m})\end{array}$ & $\begin{array}{c}\text { Description of Changes in Lithography } \\
\text { Technology that Enabled the New DRAM } \\
\text { Generation }^{\mathrm{a}}\end{array}$ & $\begin{array}{l}\text { Major Changes in Critical Relationships } \\
\text { Between Components }\end{array}$ & $\begin{array}{l}\text { Type of } \\
\text { Innovation }\end{array}$ \\
\hline 1K (1970) & $>8$ & N.A. & & N.A. \\
\hline 4K (1974) & 8.0 & $\begin{array}{l}\text { Mask is now separated from the wafer with a } \\
\text { tiny gap to improve the process yield. }\end{array}$ & & Incremental \\
\hline 16K (1976) & 5.0 & $\begin{array}{l}\text { Improvements in mask making process and } \\
\text { resist chemistry to print smaller circuits. }\end{array}$ & & Incremental \\
\hline 64K (1979) & 3.0 & $\begin{array}{l}\text { UV light is passed through reflective lens } \\
\text { system of the alignment equipment and through } \\
\text { the mask on to the wafer. }\end{array}$ & $\begin{array}{l}\text { Interaction between mask and alignment tool. } \\
\text { Manufacturing performance is now driven by } \\
\text { mask as compared to the alignment equipment. }\end{array}$ & Architectural \\
\hline 256K (1982) & 1.6 & $\begin{array}{l}\text { UV light is projected through refractive lens } \\
\text { system on only a part of the wafer at any one } \\
\text { time; the mask is shifted across the wafer in } \\
\text { steps, such that multiple exposures are made } \\
\text { across the wafer to complete the lithography } \\
\text { process. The pattern on the mask is 5-10 times } \\
\text { the DRAM circuits. }\end{array}$ & $\begin{array}{l}\text { Interaction between the mask and the alignment } \\
\text { equipment changes from scanning to stepping. } \\
\text { Minimum feature size is now driven by the } \\
\text { interaction between the tool and the resist. }\end{array}$ & Architectural \\
\hline $1 \mathrm{M}(1985)$ & 1.2 & $\begin{array}{l}\text { Improvement in resist chemistry to achieve } \\
\text { smaller feature size. }\end{array}$ & & Incremental \\
\hline 4M (1988) & 0.8 & $\begin{array}{l}\text { An increase in the size of the lens in the } \\
\text { alignment equipment and improvement in resist } \\
\text { material. }\end{array}$ & & Incremental \\
\hline 16M (1991) & 0.5 & $\begin{array}{l}\text { Reduction in the wavelength of UV light from } \\
435 \mathrm{~nm} \text { to } 365 \mathrm{~nm} \text { accompanied by changes in } \\
\text { the resist material to absorb lower wavelength } \\
\text { light. }\end{array}$ & $\begin{array}{l}\text { Relationship between the alignment equipment } \\
\text { and the resist due to change in wavelength from } \\
438 \text { to } 365 \text { nanometers (nm). }\end{array}$ & Architectural \\
\hline 64M (1995) & 0.35 & $\begin{array}{l}\text { Increase in the size of the lens of the alignment } \\
\text { equipment; improvement in mask making } \\
\text { process and resist material. }\end{array}$ & & Incremental \\
\hline $\begin{array}{l}128 \mathrm{M} \\
(1998)\end{array}$ & 0.30 & $\begin{array}{l}\text { Increase in the size of the lens and } \\
\text { improvement in mask and resist components. }\end{array}$ & & Incremental \\
\hline $\begin{array}{l}256 \mathrm{M} \\
(2000)\end{array}$ & 0.25 & $\begin{array}{l}\text { Reduction in the wavelength of UV light from } \\
365 \mathrm{~nm} \text { to } 248 \mathrm{~nm} \text { accompanied by changes in } \\
\text { the resist and mask material to absorb lower } \\
\text { wavelength light. }\end{array}$ & $\begin{array}{l}\text { Absorption of the low wavelength light by the } \\
\text { mask and the resist becomes a key bottleneck to } \\
\text { reducing the feature size. New mask techniques } \\
\text { such as phase shift mask (PSM) and optical } \\
\text { proximity correction (OPC) are employed to get } \\
\text { smaller features. }\end{array}$ & Architectural \\
\hline $\begin{array}{l}512 \mathrm{M} \\
(2001)\end{array}$ & 0.23 & $\begin{array}{l}\text { Increase in numerical aperture of the lens; } \\
\text { improvement in mask making process and } \\
\text { resist material. }\end{array}$ & & Incremental \\
\hline $1 \mathrm{G}(2003)$ & 0.18 & $\begin{array}{l}\text { Increase in numerical aperture of the lens, } \\
\text { improvement in mask and resist materials. }\end{array}$ & & Incremental \\
\hline
\end{tabular}

${ }^{a}$ For details of changes in lithography technology, please refer to Kapoor and Adner (2007) 
Table 3

Probit Estimates for First-stage Governance Choice Model for Mask $(B u y=1$, Make=0)

\begin{tabular}{|l|c|c|c|}
\hline & $(1)$ & $(2)$ & $(3)$ \\
\hline Firm Size & $-0.522^{* * *}$ & $-0.923^{* * *}$ & $-0.997^{* * *}$ \\
\hline Firm Scope & $(0.100)$ & $(0.162)$ & $(0.174)$ \\
\hline & $-2.280^{* * *}$ & $-1.165^{* *}$ & -0.843 \\
\hline Mask Knowledge & $(0.372)$ & $(0.511)$ & $(0.550)$ \\
\hline & $0.032^{*}$ & 0.020 & $0.033^{*}$ \\
\hline DRAM Feature Size & $(0.017)$ & $(0.015)$ & $(0.017)$ \\
\hline & & $-0.783^{* * *}$ & $-0.964^{* * *}$ \\
\hline Number of Suppliers & & $(0.194)$ & $(0.214)$ \\
\hline & & & $0.244^{* * *}$ \\
\hline Constant & $4.541^{* * *}$ & $6.362^{* * *}$ & $5.504 * * *$ \\
\hline & $(0.710)$ & $(0.924)$ & $(0.974)$ \\
\hline Log-likelihood & -71.60 & -62.81 & -58.32 \\
\hline Incremental $\chi^{2}$ & & $17.58^{* * *}$ & $8.98^{* * *}$ \\
\hline Observations & 166 & 166 & 166 \\
\hline
\end{tabular}

Robust standard errors in parenthesis.

$*$ significant at $10 \%$; ** significant at $5 \%$; *** significant at $1 \%$. 
Table 4

Descriptive Statistics and Correlations

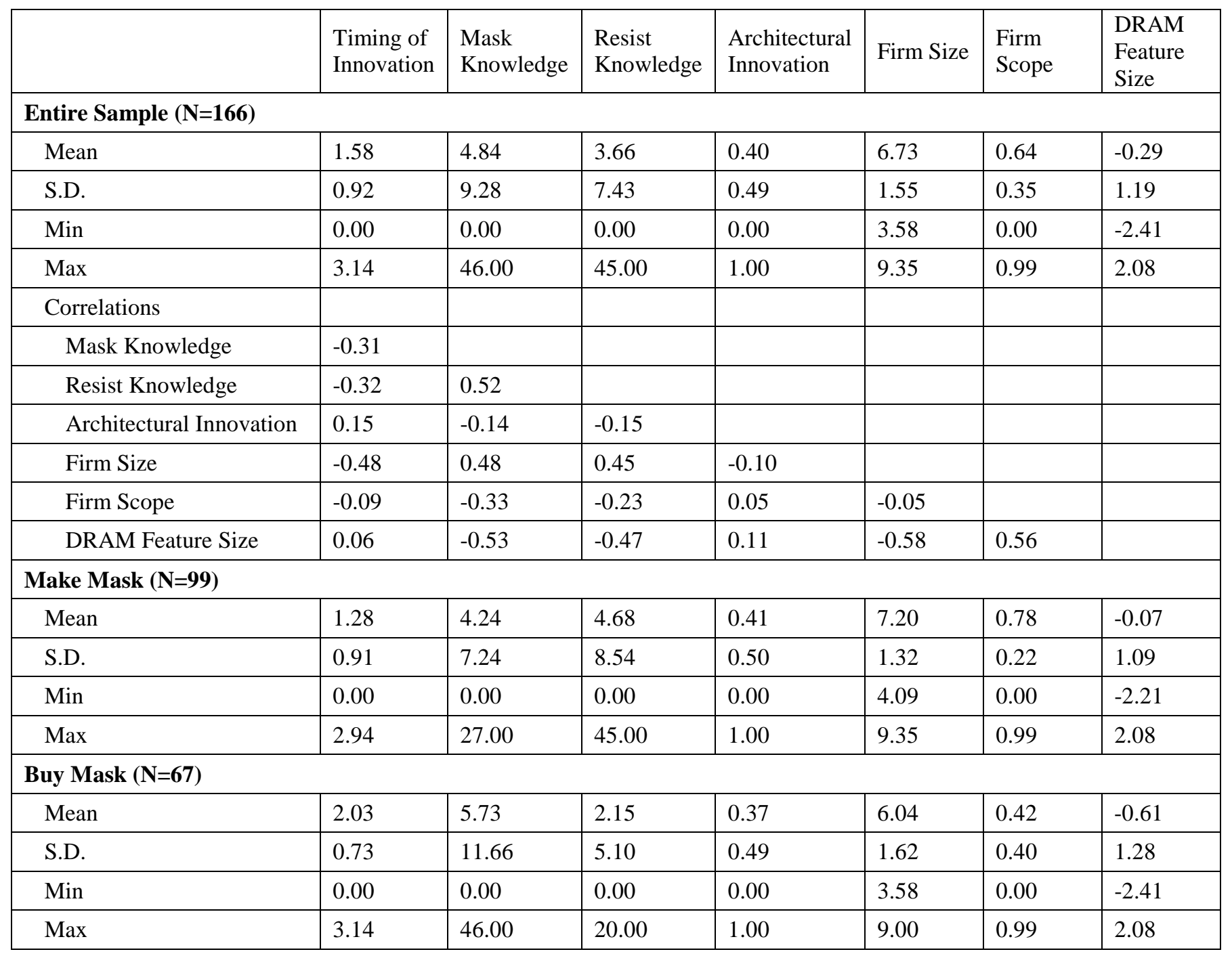

All correlations above 0.2 are significant at $\mathrm{p}<0.05$ 
Table 5

Second Stage Regression Results for the Firm's Log (Timing of Innovation) ${ }^{\text {a }}$

\begin{tabular}{|c|c|c|c|c|c|c|c|c|}
\hline & \multirow[t]{2}{*}{$(1)$} & \multirow[t]{2}{*}{$(2)$} & \multicolumn{2}{|c|}{ (3) } & \multicolumn{2}{|c|}{ (4) } & \multicolumn{2}{|c|}{ (5) } \\
\hline & & & Make Mask & Buy Mask & Make Mask & Buy Mask & Make Mask & Buy Mask \\
\hline \multirow[t]{2}{*}{ Mask Governance (Buy) } & $0.404 * *$ & $1.568 * * *$ & & & & & & \\
\hline & $(0.188)$ & $(0.472)$ & & & & & & \\
\hline \multirow[t]{2}{*}{ Mask Knowledge } & $-0.026 * * *$ & $-0.031 * * *$ & $-0.026^{*}$ & $-0.036 * * *$ & $-0.026 * *$ & $-0.024 * * *$ & $-0.026^{* *}$ & $-0.020 * * *$ \\
\hline & $(0.009)$ & $(0.008)$ & $(0.012)$ & $(0.007)$ & $(0.012)$ & $(0.007)$ & $(0.012)$ & $(0.006)$ \\
\hline \multirow[t]{2}{*}{ Resist Knowledge } & & & & & 0.004 & $-0.039 * *$ & 0.004 & $-0.039 * * *$ \\
\hline & & & & & $(0.017)$ & $(0.014)$ & $(0.017)$ & $(0.012)$ \\
\hline \multirow[t]{2}{*}{ Architectural Innovation } & & & & & & & -0.016 & $0.367 * * *$ \\
\hline & & & & & & & $(0.132)$ & $(0.090)$ \\
\hline \multirow[t]{2}{*}{ Firm Size } & $-0.297 * * *$ & -0.055 & -0.224 & 0.092 & -0.231 & 0.055 & -0.230 & 0.023 \\
\hline & $(0.080)$ & $(0.127)$ & $(0.254)$ & $(0.115)$ & $(0.247)$ & $(0.108)$ & $(0.250)$ & $(0.087)$ \\
\hline \multirow[t]{2}{*}{ Firm Scope } & 0.367 & $0.822 * * *$ & $1.646 * *$ & $0.626 * *$ & $1.676 * *$ & $0.578 * *$ & $1.677 * *$ & $0.510 *$ \\
\hline & $(0.228)$ & $(0.279)$ & $(0.683)$ & $(0.257)$ & $(0.708)$ & $(0.269)$ & $(0.711)$ & $(0.249)$ \\
\hline \multirow[t]{2}{*}{ DRAM Feature Size } & $-0.310 * * *$ & -0.116 & -0.210 & -0.126 & -0.204 & $-0.176^{*}$ & -0.203 & $-0.188 *$ \\
\hline & $(0.101)$ & $(0.117)$ & $(0.237)$ & $(0.100)$ & $(0.243)$ & $(0.096)$ & $(0.245)$ & $(0.102)$ \\
\hline \multirow[t]{2}{*}{ Inverse Mill's Ratio $(\lambda)$} & & $-0.753 * *$ & -0.702 & $-0.844 * *$ & -0.669 & $-0.707 * *$ & -0.672 & $-0.589 *$ \\
\hline & & $(0.309)$ & $(0.602)$ & $(0.307)$ & $(0.559)$ & $(0.328)$ & $(0.568)$ & $(0.298)$ \\
\hline \multirow[t]{2}{*}{ Constant } & $3.220 * * *$ & 0.910 & 1.472 & $1.741 * * *$ & 1.494 & $1.908 * * *$ & 1.493 & $1.905 * * *$ \\
\hline & $(0.511)$ & $(1.083)$ & $(2.323)$ & $(0.612)$ & $(2.310)$ & $(0.574)$ & $(2.329)$ & $(0.477)$ \\
\hline R-squared & 0.37 & 0.40 & 0.32 & 0.47 & 0.32 & 0.51 & 0.32 & 0.57 \\
\hline Observations & 166 & 166 & 99 & 67 & 99 & 67 & 99 & 67 \\
\hline
\end{tabular}

${ }^{a}$ Lower value of dependent variable implies superior performance i.e., earlier timing of innovation.

Standard errors in parentheses, clustered by firm.

* significant at 10\%; ** significant at 5\%; *** significant at 1\% (two-tailed t-test). 